\title{
KOMPATIBILITAS ISLAM DAN DEMOKRASI: TANTANGAN DAN HAMBATAN DEMOKRATISASI DI DUNIA ISLAM
}

\author{
Abdul Jalil \\ Badan Penelitian dan Pengembangan dan Pendidikan dan Pelatihan-Kementerian Agama \\ abduljalil.ruby@gmail.com
}

https://doi.org/10.36052/andragogi. v8i1.121

Diterima: 11 April 2020 | Disetujui: 29 Juni 2020 | Dipublikasikan: 30 Juni 2020

\begin{abstract}
Abstrak
Penelitian ini bertujuan untuk mengetahui apakah Islam dan demokrasi itu kompatibel, serta bagaimana tantangan dan hambatan demokratisasi di dunia Islam. Penelitian ini bercorak pustaka murni (library research) dengan menggunakan metode deskriptif kualitatif. Analisis data terhadap bahasan tersebut menggunakan pendekatan induktif, yaitu mengambil kesimpulan umum dari kesimpulan khusus. Pada prinsipnya, tidak semua ajaran demokrasi relevan dengan ajaran Islam. Ketika demokrasi menjadi komitmen bagi negara untuk dipraktikkan, maka semua aspek kehidupan tidak lepas dari sentuhan demokrasi, termasuk agama. Di negara-negara muslim terutama Asia dan Afrika Utara, demokrasi agama tidak serta merta beriringan dengan praktik demokrasi politik. Secara doktrinal, Islam dan demokrasi adalah dua hal yang berbeda, namun secara substantif ada prinsip-prinsip demokrasi yang kompatibel (sesuai) dengan ajaran Islam. Prinsip keadilan dalam penegakan hukum, persamaan dalam kehidupan bermasyarakat, berbangsa dan bernegara, serta kebebasan berpendapat, beragama dan berkeyakinan. Prinsip-prinsip ini secara ideal tertuang dalam dokumen tertulis, yaitu Piagam Madinah.
\end{abstract}

Kata Kunci: Islam, Demokrasi, Piagam Madinah

\begin{abstract}
[THE COMPATIBILITY OF ISLAM AND DEMOCRACY: CHALLENGES AND OBSTACLES OF DEMOCRATIZATION IN ISLAMIC WORLD] This study aims to find out whether Islam and democracy are compatible, as well as how the challenges and obstacles of democratization in the Muslim world. This research is in the form of a pure library (library research) using descriptive qualitative methods. Data analysis of the discussion uses the inductive approach, which is to draw general conclusions from specific conclusions. In principle, not all democratic teachings are relevant to Islamic teachings. When democracy becomes a commitment for the state to be put into practice, then all aspects of life cannot be separated from a touch of democracy, including religion. In Muslim countries, especially Asia and North Africa, religious democracy does not necessarily go hand in hand with the practice of political democracy. Doctrinally, Islam and democracy are two different things, but substantively there are democratic principles that are compatible with Islamic teachings. The principle of justice in law enforcement, equality in community life, nation and state, as well as freedom of opinion, religion, and belief. These principles are ideally contained in a written document, the Medina Charter.
\end{abstract}

Keywords: Islam, Democracy, Madina Charter

This work is licensed under a Creative Commons Attribution-NonCommercial 4.0 International License 


\section{PENDAHULUAN}

$I$ stilah demokrasi identik dengan kekuasaan rakyat (Salamadian, 2018), yaitu konsep klasik untuk menunjukkan adanya sistem kekuasaan dan pemerintahan partisipatif serta konstitusi yang sah. Demokrasi bukanlah suatu doktrin yang absolut dan dogmatis, melainkan sesuatu yang terbuka untuk diperdebatkan. Di kalangan para pemikir muslim, persoalan demokrasi telah menjadi "wacana" yang hingga kini masih hangat diperbincangkan. Pembicaraan mengenai kompatibitas antara Islam dan demokrasi menjadi objek bahasan yang mewarnai perdebatan tersebut.

Secara metodologis, membandingkan antara Islam dan demokrasi tidaklah tepat, karena Islam merupakan agama dan risalah yang mengandung asas-asas yang mengatur ibadah, akhlak, dan muamalah manusia. Sedangkan demokrasi hanyalah gagasan atau pandangan hidup yang mengutamakan persamaan hak dan kewajiban serta perlakuan yang sama bagi semua warga negara (Depdikbud, 1999:220).

Dengan demikian, secara doktrinal, Islam dan demokrasi tidak memiliki hubungan khusus, baik istilah, bentuk pelaksanaan, maupun sejarahnya. Islam secara absolut diturunkan Allah SWT melalui RasulNya Muhammad saw, adapun demokrasi merupakan produk manusia yang pencetus idenya seorang filosuf Yunani bernama Solon Kleistenes (hidup kurang lebih 600 tahun SM). Ketika itu, Solon mengadakan reformasi terhadap sistem pemerintahan di kota Athena. Namun secara substantif, Islam dan demokrasi memiliki keterkaitan dalam nilai-nilai dasar berupa asas kebebasan, keadilan, dan kerjasama ( $\mathrm{Hasbi}_{\text {, }}$ 2001:xxxiii-xxxiv).

Realitasnya, tidak semua kalangan umat Islam menerima sistem demokrasi. Sebagian mereka memandang bahwa demokrasi sekarang ini bukan sebagai bentuk pemerintahan yang berdasarkan kepada kebebasan, kerja sama politik, pluralisme, dan sebagainya, tetapi dipandangnya sebagai rumusan bagi konsep Barat yang memengaruhi pemikiran umat
Islam. Sikap seperti ini merupakan dampak psikologis dari pengalaman masa lalu sebagian umat Islam terhadap Barat. Reaksi negatif tersebut sebagai ungkapan dari penolakan secara radikal terhadap kolonialisme Eropa, dan pembelaan terhadap Islam dalam upaya mengurangi ketergantungan umat Islam terhadap negara-negara Barat (Esposito \& Picatori, 1991; Huwaydi, 1993)

Aksi-aksi kekerasan, penindasan, intimidasi, serta perlakuan tidak adil negaranegara Barat terhadap negara-negara Muslim yang seringkali terjadi, bahkan hingga sekarang seperti yang menimpa Palestina, Irak, Suriah, dan Iran, menjadi alasan kuat bagi sebagian kalangan umat Islam untuk menolak keberadaan sistem demokrasi.

Pada tulisan ini dirumuskan pokok masalah, antara lain:

1. Apakah Islam dan demokrasi itu kompatibel?

2. Bagaimana tantangan dan hambatan demokratisasi di dunia Islam?

Tulisan ini bertujuan untuk mengetahui apakah Islam dan demokrasi itu kompatibel, serta bagaimana tantangan dan hambatan demokratisasi di dunia Islam. Tulisan ini hendak mengkaji persamaan dan perbedaan Islam dan demokrasi dalam pandangan para pemikir muslim, serta realitas demokratisasi di dunia Islam.

\section{KAJIAN TEORITIS}

\section{Din al-Islam}

Dalam al-Qur'an ada dua ayat yang secara tegas menyatakan bahwa Islam itu al-din (agama). Pertama, surat Ali 'Imran/3:19 yang berbunyi:

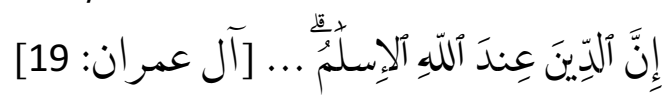

"Sesungguhnya agama (yang diridhai) disisi Allah hanyalah Islam..." [QS Ali 'Imran/3:19].

Kedua, tercantum dalam surat alMaidah/5:3 sebagai berikut:

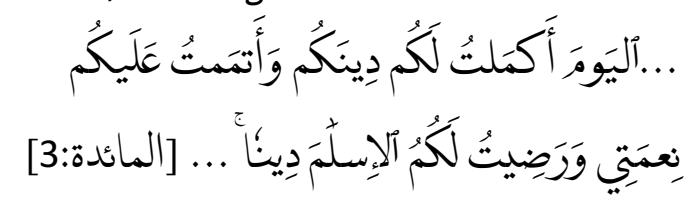

“... Pada hari ini telah Kusempurnakan untuk kamu agamamu, dan telah Kucukupkan 
kepadamu nikmatKu, dan telah Kuridhai Islam sebagai agama bagimu..." [QS al-Maidah/5:3].

Perkataan al-din yang tercantum dalam QS Ali 'Imran/3:19 dan QS al-Maidah/5:3 merupakan suatu konsep yang mengandung dua komponen hubungan, yaitu hubungan vertikal dengan Allah (hablun min Allah), dan hubungan khorizontal antara manusia dengan manusia dalam suatu masyarakat atau negara, bahkan mungkin antar negara, serta antar manusia dengan lingkungan hidupnya (QS Ali 'Imran/3:112). Dengan demikian, istilah al-din dalam al-Qur'an mengandung konsep bidimensional yang mencakup dua aspek kehidupan manusia, yakni aspek religiusspiritual (agama-ketuhanan) dan aspek kemasyarakatan yang bertumpu pada ajaran tauhid (Azhary, 1992:22).

Dalam Bahasa Arab, istilah agama sering disebut dengan al-din. Secara konseptual, sesungguhnya perkataan agama dan al-din mengandung konotasi masing-masing yang berbeda. Perkataan agama yang sudah lazim digunakan dalam Bahasa Indonesia berasal dari Bahasa Sanskerta yang memiliki konotasi sangat erat dengan tradisi dalam agama Hindu dan Budha. Menurut M. Rasjidi, penggunaan kata agama sebagai terjemah dari al-din hanyalah sekadar untuk memudahkan berkomunikasi (Rasjidi, H. M., 1989:15). Rusydi Muhammad 'ulyan dan Fithan 'Abd alRahman al-Ruriy mendefinisikan agama sebagai berikut:

$$
\begin{aligned}
& \text { وضع إلهي سائق لذوي العقول باختيارهم إياه } \\
& \text { إلى الصلاة في الحال والفلاح في المآل }
\end{aligned}
$$

"Aturan Tuhan yang mengarahkan orang-orang berakal agar memilih aturan tersebut untuk meraih kemaslahatan di dunia dan mencapai kebahagiaan di akhirat" ('Ulyan, Rusydi Muhammad \& Al-Ruriy, Fithan 'Abd al-Rahman, 1986:22).

Dari sudut kebahasaan, kata al-din memiliki banyak arti, antara lain: taat, ibadah, pembalasan, pembenaran, pengakuan atas jasa, dan utang. Makna-makna tersebut dihimpun oleh adanya hubungan antara dua pihak (Syihab, 2018:35). Pihak pertama adalah Allah sebagai al-Khaliq yang kedudukannya lebih tinggi, sedangkan pihak kedua yaitu manusia sebagai makhluk yang kedudukannya lebih rendah. Dari sinilah terjadi hubungan timbal balik antara hamba dengan Tuhannya. Makna al-din mempunyai korelasi dengan kata Islam, bentuk mashdar dari aslama yang secara harfiah berarti: "al-inqiyad wa al-khudhu' (tunduk dan taat)." Karena itu, orang yang menyatakan dirinya tunduk serta patuh pada ajaran-ajaran Allah yang dibawa oleh RasulNya Muhammad saw dinamakan muslim.

Louis Ma'luf, menjelaskan pengertian Islam sebagai wujud ketundukan secara mutlak terhadap risalah Ilahiah (agama) yang dibawa oleh Nabi Muhammad saw () إظهار الخضوع) و القبول لما أنى به/الدين الذي جاء بـ محمد صلى الله عليه وسلم (Ma'luf, 2003, p. 347). Pandangan ini dipertegas oleh Razw al-Thawil yang mengatakan, Islam adalah "agama yang hak dan diridhai Allah bagi manusia" (Thawil, 1984:17). Di kalangan mayoritas ulama, Islam dinisbatkan kepada agama terakhir yang disampaikan melalui lisan Rasulullah saw, sehingga sering disebut dengan "din al-Islam." Dengan demikian, Islam lebih dikenal menjadi sebuah nama agama, dan umat Islam merupakan pemeluknya.

Din al-Islam sebagai agama wahyu terakhir, mengandung ajaran yang terdiri dari tiga komponen: akidah (iman, keyakinan), syariah (hukum), dan akhlak (moral) yang mengatur segala tingkah-laku manusia dalam berbagai hubungan, baik hubungan manusia dengan Tuhannya, maupun hubungan manusia dengan dirinya sendiri, masyarakat, benda atau makhluk lainnya (Ali, 1990:28). Ketiga komponen itu merupakan totalitas yang integral (tidak dapat dipisahkan), sebab dalam tiga komponen ini pula terlibat tiga faktor yang saling berkaitan, yaitu posisi Allah, manusia, dan alam lingkungan hidup. Dalam din al-Islam, Allah menempati posisi yang sangat sentral, karena Dialah yang menciptakan manusia dan alam semesta ini (QS al-Ra'd/13:16; QS alAn'am/6:73; QS al-Baqarah/2:29).

Sayyed Hossein Nasr menyatakan, Islam bukan hanya sekadar agama yang mengandung seperangkat doktrin ritual, tetapi ia merupakan suatu pandangan dunia holistik yang menyeluruh dan sistematis (Nasr, 1983:1113). Pernyataan ini dikuatkan dengan pendapat Muhammad Tahir Azhary, bahwa Islam sebagai 
al-din mencakup seluruh aspek kehidupan manusia. Oleh karenanya, aspek-aspek kenegaraan dan hukum merupakan bagian dari din al-Islam (Azhary, 1992:24). Pandangan yang sama juga diungkapkan W. Montgomery Watt, konotasi kata din dalam Bahasa Arab meskipun dapat diterjemahkan menjadi agama, sangatlah berbeda dengan kata religion dalam Bahasa Inggris, sebab din dapat meliputi seluruh bentuk kehidupan, sedangkan 'religion' tidak (Watt, 1987:35). M. Rasjidi menjelaskan, konotasi kata religion menonjolkan ikatan manusia dengan kelompoknya di samping dengan dewanya (Rasjidi, H. M., 1989:15). Konsep religion sebagaimana dipahami dalam sejarah Barat memiliki ruang lingkup yang terbatas, terutama pada soal-soal pribadi manusia. Keterbatasan substansi religion dilukiskan oleh Bernard Lewis seperti halnya dalam agama Kristen, hanya suatu sektor atau segmen kehidupan, mengatur beberapa hal, sementara yang lainnya tersingkirkan (Lewis, 1983:11).

\section{Konsep Demokrasi}

Demokrasi berasal dari kata demos yang berarti rakyat, dan kratos/kratein yang artinya kekuasaan. Demokrasi dapat diartikan "rakyat berkuasa" atau "government rule by people" (Budiardjo, 2004:50). Berdasarkan itu, demokrasi berarti pemerintahan dari rakyat, oleh rakyat, dan untuk rakyat dengan menjalankan peraturan yang dibuat sendiri oleh rakyat. Demokrasi lahir bermula dari adanya para penguasa di Eropa (abad pertengahan) yang beranggapan, penguasa adalah wakil Tuhan di bumi, dan berhak memerintah rakyat berdasarkan kekuasaan Tuhan. Mereka beranggapan bahwa Tuhan telah memberi kewenangan kepada mereka membuat hukum dan menerapkannya. Dengan dasar inilah mereka menzalimi dan menguasai rakyat, sebagaimana pemilik budak menguasai budaknya. Lalu timbullah pergolakan antara penguasa Eropa dengan rakyatnya.

Para filosuf dan pemikir mulai membahas masalah pemerintah serta menyusun konsep sistem pemerintahan rakyat, yaitu sistem demokrasi di mana rakyat menjadi sumber kekuasaan dalam sistem tersebut. Penguasa mengambil sumber kekuasaannya dari rakyat yang menjadi pemilik kedaulatan. Rakyat adalah ibarat pemilik budak yang berhak membuat peraturan yang akan mereka terapkan, serta menjalankannya sesuai dengan keinginannya. Rakyat berhak pula mengangkat penguasa untuk memerintah rakyat, karena posisinya sebagai wakil rakyat dengan peraturan yang dibuat oleh rakyat. Karena itu, sumber kemunculan sistem demokrasi seluruhnya adalah manusia, dan tidak ada hubungannya sama sekali dengan wahyu atau agama (Sudjana, 1998:45).

Salah satu sifat demokrasi adalah kemampuannya untuk menghilangkan bentukbentuk kekuasaan yang absolut, karena paham absolutism menyebabkan kediktatoran. Untuk mengatasi hal tersebut, maka lahirlah konsep Trias Politika yang dicetuskan oleh seorang filosuf dari Prancis, Montesquieu. Konsep inilah yang disebut-sebut sebagai ukuran demokratis tidaknya suatu negara. Menurut Trias Politika, kekuasaan negara terdiri dari tiga macam, yaitu: kekuasaan legislatif (pembuat undangundang); kekuasaan eksekutif (pelaksana undang-undang); kekuasaan yudikatif (yang mengadili atas pelanggaran undang-undang).

Konsep Trias Politika merupakan ide pokok dalam demokrasi Barat yang mulai berkembang di Eropa antara abad ke-17 sampai dengan abad ke-18 M. Konsep tersebut untuk pertama kali dikemukakan oleh John Locke (1632-1704) dan Montesquieu (1689-1755). Pembagian kekuasaan menurut Trias Politika menggambarkan bahwa rakyatlah yang menjadi sumber kekuasaan legislatif, eksekutif, dan yudikatif. Dengan demikian, rakyatlah yang menetapkan peraturan dan undang-undang, menentukan para hakim serta mengangkat para penguasa. Dari sini tampak jelas bahwa konsep Trias Politika bertujuan untuk memelihara kebebasan politik warga negara yang hilang karena perilaku penguasa yang bertindak sewenang-wenang. Maka kebebasan menjadi prinsip yang harus diwujudkan oleh demokrasi bagi setiap individu rakyat, yakni kebebasan beragama, kebebasan berpendapat, kebebasan kepemilikan, dan kebebasan bertingkah laku. 


\section{METODE PENELITIAN}

Penelitian ini bercorak pustaka murni (library research) dengan menggunakan metode deskriptif kualitatif. Penelitian deskripsi menggambarkan suatu situasi fenomena secara detail dan lebih menekankan pada menjawab pertanyaan "how" (bagaimana) dan "who" (siapa). Tujuan dari penelitian deskriptif adalah membuat deskripsi, gambaran atau lukisan secara sistematis serta hubungan antar fenomena yang diselidiki. Sedangkan penelitian kualitatif adalah penelitian yang bersifat deskriptif dan cenderung menggunakan analisis, serta lebih menonjolkan proses dan makna (perspektif subjek). Bogdan dan taylor mendefinisikan penelitian kualitatif "sebagai prosedur penelitian yang menghasilkan data deskriptif berupa kata-kata tertulis atau lisan dari orang-orang dan perilaku yang dapat diamati" (Moleong, 1991:3).

Jenis penelitian deskriptif kualitatif merupakan sebuah metode penelitian yang memanfaatkan data kualitatif dan dijabarkan secara deskriptif untuk menganalisis kejadian, fenomena, atau keadaan secara sosial. Analisis data terhadap bahasan tersebut menggunakan pendekatan induktif, yaitu menarik kesimpulan dari hal-hal yang khusus untuk menuju kesimpulan yang bersifat umum. Selama kajian berlangsung, seluruh argumentasi yang mendukung penyusunan tulisan ini adalah bersumber dari buku-buku, jurnal, dan tulisantulisan ilmiah yang memiliki keterkaitan dengan objek yang dikaji. Berdasarkan itu, data-data yang bersumber dari bahan-bahan tertulis tentang Islam dan demokrasi akan dianalisis untuk dideskripsikan dalam tulisan ini.

\section{TEMUAN DAN PEMBAHASAN}

\section{Temuan}

\subsection{Pandangan Pemikir-Pemikir Muslim}

Pergulatan Islam dan demokrasi menjadi diskursus di kalangan pemikir Muslim. Paling tidak ada tiga kelompok yang pandangannya menjadi rujukan berkaitan dengan "Islam dan demokrasi." Pertama, kelompok konservatif, yang tetap mempertahankan integrasi antara Islam dan negara, sebab menurut kelompok ini, Islam telah lengkap mengatur sistem kemasyarakatan. Kelompok ini terdiri dari: tradisionalis, yakni yang tetap mempertahankan tradisi praktik dan pemikiran politik Islam klasik/pertengahan, seperti Rasyid Ridha, dan fundamentalis, yaitu yang ingin melakukan reformasi sistem sosial dengan kembali kepada ajaran Islam secara total, serta menolak sistem yang dibuat manusia. Tokohtokohnya seperti: Sayyid Quthb, Abu al-A'la alMaududi, dan Hasan Turabi (Abdillah, 2001:xii). Istilah fundamentalis muncul pertama kali di kalangan para penganut Kristen Protestan di Amerika Serikat, sekitar tahun 1910-an. Mereka ini merupakan bagian dari fenomena responsi kalangan konservatif terhadap perkembangan teologi liberalmodernisme dan gejala sekularisme dan gejala sekularisme. Gerakan ini ditandai dengan terbitnya 12 buku kecil yang berjudul "The Fundamentals: A Testimony of the truth," yang sejak saat itu jutaan eksemplar buku-buku tersebut disebarkan. Ada beberapa pokok pandangan doktrin yang terutama dalam gerakan ini, yakni pemahaman literal mengenai ketidak keliruan Injil, sifat Ketuhanan Kristus, kebangkitannya secara fisik, dan turunnya kembali ke dunia secara fisik pula. Semua ini menegaskan tentang penolakan mereka terhadap pemahaman para teolog modernisliberal, yang menjelaskan pemahaman teologi mereka sesuai dengan perkembangan ilmu pengetahuan dan zaman modern. Adapun ciriciri dari gerakan fundamentalisme ini terutama militansinya untuk membela dan mempertahankan keyakinan mereka (Hadimulyo, 1993:5).

Kedua, kelompok modernis dan neomodernis, yang berpendapat bahwa Islam mengatur masalah keduniaan (kemasyarakatan) hanya secara dasar-dasarnya saja. Adapun secara teknis dapat mengadopsi sistem lain, yang dalam hal ini adalah sistem Barat yang sudah menunjukkan kelebihannya. Di antara kelompok ini adalah Muhammad Abduh, Husein Haikal, dan Muhammad Assad. Ketiga, kelompok sekuler atau liberal, yang ingin memisahkan antara Islam dengan negara. Menurut kelompok ini, Islam tidak mengatur masalah keduniaan sebagaimana praktik kenegaraan yang terdapat di Barat. Di antara tokoh aliran ini adalah 'Ali Abd al-Raziq dan Thaha Husein (Sjadzali, 1990:1-2). 
Pada umumnya, kelompok pertama (konservatif) menolak sistem demokrasi, dengan alasan karena demokrasi yang mengandung pengertian kedaulatan rakyat (siyadah al-ummah), berarti meniadakan kedaulatan Tuhan (Abdillah, 2001:xiii). Kelompok ini diprakarsai oleh Sayyid Quthb dengan mengembangkan konsep tauhid 'hakimiyah' yang berarti penerimaan hanya hukum-hukum Allah semata yang harus diaplikasikan dalam kehidupan masyarakat dan negara (Abdillah, 2001:xiii).

Namun Yusuf Qardhawy yang sebenarnya termasuk kelompok pertama (konservatif), menerima sistem demokrasi, karena substansi demokrasi sejalan dengan Islam. Menurut Qardhawy, hakikat demokrasi adalah bahwa rakyat memilih orang yang akan memerintah dan menata persoalan mereka tanpa paksaan, dan tidak boleh mereka dipaksa untuk menerima penguasa atau rezim yang mereka benci. Oleh karena itu, rakyat diberi hak untuk mengoreksi penguasa bila keliru, dan diberi hak untuk mencabut serta menggantinya jika menyimpang. Sedangkan proses memilih penguasa, dapat dilakukan dengan berbagai bentuk dan cara praktis, seperti pemilihan umum dan referendum, mendukung pihak mayoritas, menerapkan sistem multi partai, memberikan hak kepada minoritas untuk beroposisi, menjamin kebebasan pers dan kemandirian keadilan (Qardhawy, 1997:167).

Sementara itu, al-Maududi mencoba menawarkan istilah "theo-democracy," karena menurutnya, kedaulatan Tuhan maupun kedaulatan rakyat terdapat dalam negara yang mempraktikkan syariat Islam, walaupun kedaulatan rakyat ini terbatas hanya pada konteks penyelenggaraan negara serta urusanurusan administratif dan hal-hal lain yang tidak terdapat dalam Syariah (Maududi, 1960:147148). Berdasarkan konsepsi tersebut, kedaulatan yang sesungguhnya berada pada Tuhan, dan negara berfungsi sebagai kendaraan politik untuk menerapkan hukum-hukum Tuhan. Sejalan dengan al-Maududi, Dhiyauddin Rais berpendapat bahwa di dalam Islam terdapat kedaulatan rakyat dan kedaulatan hukum Syariah sekaligus. Karena itu, seandainya dibuat istilah, sistem pemerintahan Islam dapat dikatakan sebagai sistem demokrasi humanis, universal, religius, moralis, material dan spiritual (Rais, 2001:312).

Pada tahun 1952-1958, Muhammad Natsir sebagai ketua Masyumi mendukung demokrasi, walaupun mempunyai penafsiran berbeda tentang demokrasi. Dalam pandangannya, Islam adalah sistem demokrastis, dalam pengertian bahwa Islam menolak despotisme, absolutisme, dan otoritarianisme. Islam adalah sintesis antara demokrasi dan otokrasi. Artinya semua urusan dalam pemerintahan Islam diputuskan melalui Majelis Syura (Dewan permusyawaratan). Keputusan-keputusan demokratis diterapkan hanya pada permasalahan yang tidak disebutkan secara khusus dalam syariah. Atas dasar itu, tidak ada keputusan demokratis pada hal-hal yang sudah jelas disebutkan dalam al-Qur'an, seperti pada larangan judi dan zina. Dalam hal ini, meskipun Natsir mendukung demokrasi, tetapi dia tetap mendukung kedaulatan Tuhan (Sjadzali, 1990:172).

Kelompok kedua (modernis/neomodernis), pada umumnya menerima sistem demokrasi, tetapi dengan beberapa penyesuaian. Menurut kelompok ini, secara organisatoris memang tidak ada persoalan, namun secara filosofis tentu mengandung persoalan, karena demokrasi itu didasarkan pada sekularisme, sedangkan Islam sebuah agama yang berdasarkan pada nilai-nilai Ketuhanan.

Adapun kelompok ketiga (sekuler/liberal) tidak mempunyai persoalan dengan demokrasi, karena baik secara filosofis maupun secara organisatoris (institusional), kelompok ini mendukung sistem demokrasi.

Secara teologis, penerimaan para intelektual Muslim terhadap demokrasi didasarkan pada ajaran al-Qur'an dan praktik historis masa Rasulullah saw serta al-Khulafa alRasyidun (khalifah yang empat). Mereka menyamakan konsep demokrasi dengan konsep syura, yang terdapat dalam QS al-Syura/42:38 dan QS Ali `Imran/3:159.

Dengan demikian, membicarakan demokrasi berdasarkan sudut pandang doktinal Islam tidak akan bertemu. Namun bila dilihat secara sosio-kultural, banyak nilai-nilai demokrasi yang tercakup dalam Islam. Misalnya ajaran "hablun min Allah wa hablun min al-nas," 
yaitu menjalin hubungan vertikal dengan Allah, dan komunikasi kharizontal dengan sesama umat manusia (QS Ali 'Imran/3:112). Ini menunjukkan bahwa Islam tidak hanya memerintahkan umatnya untuk berhubungan dengan Tuhannya semata, melainkan harus juga mewujudkan proses komunikasi dengan sesamanya. Di samping itu, di dalam Islam terkandung juga prinsip-prinsip persamaan, kebebasan memeluk agama, keadilan, musyawarah, dan keorganisasian yang semuanya ini secara substantif mencerminkan nilai-nilai demokrasi.

\subsection{Substansi Demokrasi: Perspektif Piagam Madinah}

Dalam al-Qur'an dan Sunnah terdapat sejumlah prinsip dasar yang sebanding dengan prinsip-prinsip demokrasi, antara lain: prinsip keadilan (al-'adl), musyawarah (syura), dan persamaan atau egaliter (al-musawah). Pada praktiknya, prinsip-prinsip tersebut menemukan bentuknya yang paling konkret dan mungkin juga paling baik di masa Rasulullah saw periode Madinah. Oleh banyak pihak, Piagam Madinah dianggap sebagai ekspresi perundang-undangan demokratis yang didasarkan atas prinsip-prinsip di atas.

Lahirnya Piagam Madinah berdasarkan konsensus antara Rasulullah saw dengan berbagai suku dan kelompok, yang kemudian dikenal dengan Shahifah, yakni suatu undangundang dasar yang mengikat anggota masyarakat Madinah dengan perjanjian. Karenanya, masyarakat Madinah sering disebut 'masyarakat Shahifah' (Ahmad, 1979:39). Dari sini tergambar bahwa di dalam Piagam Madinah termuat prinsip-prinsip dan kaidah-kaidah kenegaraan serta nilai-nilai kemanusiaan yang sebelumnya tidak pernah dikenal oleh umat manusia (Madjid, 1994:590). Piagam Madinah merupakan basic political principles (prinsipprinsip dasar politik) dalam menghadapi kemajemukan masyarakat Madinah (Prasetyo, 1994:202-203). Maka Piagam Madinah yang dianggap sebagai common platform kehidupan sosial politik komunitas Madinah waktu itu dapat dinilai sebagai dasar yang relatif demokratis.

Pembentukan masyarakat politik di bawah Piagam Madinah adalah ide pokok Rasulullah saw dalam mengimplementasikan tatanan sosial politik yang mengenal pendelegasian wewenang, yaitu adanya tatanan sosial dan politik yang diperintah oleh kemauan pribadi, melainkan secara bersama-sama, tidak oleh prinsip-prinsip ad hoc yang dapat berubah-ubah sejalan dengan kehendak pemimpin. Namun di sini diperintah oleh prinsip-prinsip yang dilembagakan dalam dokumen konsensus dasar semua anggota masyarakat, yaitu wujud konstitusi. Ad Hoc ialah "panitia penyelidik terhadap suatu bagian yang menjadi kepentingan dan tujuan akhir; format khusus yang mengenai masalah-masalah dengan segera untuk dicarikan solusinya" (MerriamWebster, 1984:56).

Heterogenitas masyarakat Madinah waktu itu (ras, suku, dan agama) dipersatukan di bawah kepemimpinan Rasulullah saw, dan itulah yang dinamakan ummah. Konotasi kata ummah sering dinisbatkan kepada komunitas muslim, tetapi dalam konteks ini, istilah ummah lebih bersifat umum dan berlaku bagi sebuah komunitas tanpa dibedakan dengan nama agama. Barakat Ahmad (Ahmad, 1979:39) menyatakan, "... In the theory the use of the term ummah during the major portion of the Apostle's career was not restricted to muslims alone" (secara teoretis, penggunaan istilah ummah adalah selama karir kerasulan, dan tidak terbatas pada komunitas muslim saja).

Kata ummah dalam Piagam Madinah dapat diinterpretasikan sebagai "negara" dengan mengacu kepada QS Ali 'Imran/3:104 dan 158. Dalam ayat tersebut, ummah identik dengan masyarakat yang mengemban suatu fungsi tertentu, yaitu menyelenggarakan keumatan, dengan menegakkan yang ma'ruf (adil, baik) dan mencegah yang munkar (zalim, tiran), serta menyelenggarakan kepentingan umum melalui jalan musyawarah. Dengan demikian, ummah yang diekspresikan dalam realitas sejarah khususnya masa Rasulullah saw periode Madinah adalah ummatan wahidah (kesatuan masyarakat). Maka masyarakat Madinah, walaupun beragam dengan segala hal, namun mereka adalah umat yang satu. Orang-orang Yahudi menjadi satu ummah dengan kaum Muslimin di bawah Piagam Madinah.

Rasulullah saw telah menyusun suatu persetujuan untuk mendapatkan ketetapan- 
ketetapan yang disepakati bersama, bukan mendirikan sebuah negara teologis. Dalam hal ini semua kelompok agama dan kelompok suku diberikan otonomi untuk memelihara tradisi serta kebiasaan mereka masing-masing. Dokumen Piagam Madinah telah memberikan dua landasan. Pertama, menjamin otonomi bagi kelompok yang beragam, kebebasan untuk memeluk agama dan melaksanakan adat istiadat, tradisi, serta persamaan hak bagi semua orang. Kedua, menekankan pada sisi demokrasi dan konsensus, bukan pada pemaksaan kehendak.

Sebagai kepala negara, Rasulullah saw berpegang pada prinsip musyawarah sebagaimana digariskan dalam al-Qur'an (QS alSyura/42:38); QS Ali 'Imran/3:159). Setiap keputusan yang ditetapkan, diambil berdasarkan musyawarah dengan para sahabat. Hal ini menunjukkan bahwa Rasulullah saw tidak bertindak otoriter dalam menjalankan politik pemerintah. Musyawarah dapat diartikan sebagai forum tukar-menukar pikiran, gagasan atau ide, termasuk saran-saran yang diajukan dalam memecahkan suatu masalah sebelum pengambilan keputusan.

Dilihat dari sudut kenegaraan, musyawarah adalah suatu prinsip konstitusional yang wajib dilaksanakan dalam pemerintahan dengan tujuan untuk mencegah lahirnya keputusan yang merugikan kepentingan umum atau rakyat. Malcolm H. Kerr (Kerr, 1966:134) mencatat, bahwa sekelompok muslim modern berpendapat, prinsip syura (musyawarah) merupakan bentuk asli dari perwakilan atau pemerintahan konstitusional dalam Islam. Sebagai suatu prinsip konstitusional, musyawarah berfungsi sebagai "rem" atau pencegah kekuasaan yang absolut dari seorang penguasa atau kepala negara (Maududi, 1984:73).

Musyawarah dapat diakhiri dengan kebulatan pendapat atau kesepakatan bersama (konsensus), yang dalam hukum Islam disebut dengan ijma', dan dapat pula diambil keputusan yang didasarkan pada suara terbanyak. Ini dicontohkan Rasulullah saw ketika menghadapi persoalan mengenai serangan orang-orang Quraisy Mekkah yang sedang mengepung Madinah dalam peristiwa perang Uhud. Ada dua pilihan, menghadapi musuh secara ofensif (melakukan serangan) atau defensif (bertahan). Secara pribadi Rasulullah saw memilih pilihan yang kedua (defensif), yaitu bertahan di kota Madinah, namun mayoritas suara dari para sahabat menginginkan supaya pasukan kaum Muslimin menyerang musuh di luar Madinah, yakni Bukit Uhud. Akhirnya keputusan diambil berdasarkan suara terbanyak (Haikal, 1982:313-318).

Musyawarah berbeda dengan demokrasi liberal yang berpegang pada rumus "setengah plus satu," atau suara mayoritas yang lebih dari separo yang berakhir dengan kekalahan suara bagi satu pihak, dan kemenangan bagi pihak lain. Dalam musyawarah yang dipentingkan adalah jiwa persaudaraan, sehingga yang menjadi tujuan bukan kemenangan untuk suatu pihak atau golongan, tetapi bagi kepentingan serta kemaslahatan umum dan rakyat.

Dalam menjalani kehidupan sosial yang majemuk di Madinah, Rasulullah saw dan umat Islam menerapkan tiga prinsip dasar yang sesuai dengan petunjuk al-Qur'an. Pertama, prinsip keadilan (al-'adalah), yaitu suatu pegangan untuk melakukan sesuatu sesuai dengan tempatnya, objektif, dan tidak berat sebelah. Di bawah pimpinan Rasulullah saw, umat Islam menjalin hubungan dengan masyarakat non Muslim tanpa melihat label agama, sehingga berbagai kasus yang terjadi ditangani dengan hukum keadilan. Misalnya, kasus pencurian yang dilakukan Fatimah binti Abi al-Asad, seorang anak pembesar dari kepala suku. Demi keadilan, Rasulullah saw menetapkan hukuman sesuai dengan perbuatan yang telah dilakukan pelaku. Hal ini dipertegas al-Qur'an, bahwa menegakkan keadilan tidak hanya berlaku untuk sesama Muslim saja, melainkan juga terhadap non Muslim yang tidak tidak memusuhi serta memerangi Islam sebagai agama (QS Mumammad/60:8-9 (Islam, Islam, $\& \mathrm{Rl}, 2010)$ ).

Kedua, prinsip egalitarian (al-musawwah), yaitu persamaan hak di antara masyarakat Muslim dan non Muslim di dalam kehidupan sosial. Prinsip persamaan dalam Islam dapat dipahami dari pernyataan al-Qur'an: 


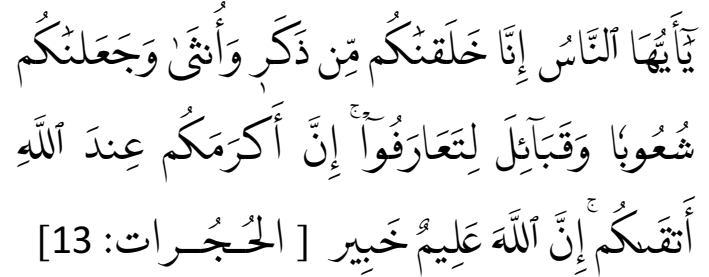

“Wahai manusia! Sungguh, Kami telah menciptakan kamu dari seorang laki-laki dan seorang perempuan, Kemudian Kami jadikan kamu berbangsa-bangsa dan bersuku-suku agar kamu saling mengenal. Sungguh orang yang paling mulia di antara kamu di sisi Allah ialah orang yang paling bertakwa. Sungguh Allah Maha Mengetahui, Mahateliti" [QS alHujurat/49:13].

Ayat tersebut menggambarkan bahwa dalam Islam manusia memiliki kedudukan yang sama. Inilah yang disebut prinsip persamaan sebagai "soko guru dari struktur sosial Islam" (Boisard, 1980:125-126). Prinsip persamaan ini mencakup dalam segala bidang kehidupan: hukum, politik, ekonomi, sosial, dan lain-lain. Menyangkut persamaan di bidang hukum, semua orang mendapat jaminan perlakuan dan perlindungan hukum yang sama tanpa memandang kedudukannya, apakah ia dari kalangan rakyat biasa atau dari kelompok elit. Rasulullah saw menegaskan dalam sebuah hadis: "Demi Allah, seandainya Fatimah putriku mencuri, tetap akan kupotong tangannya" (Riwayat Abu Daud dan Nasa'i).

Salah satu contoh konkret penerapan prinsip persamaan di masa Rasulullah saw, yaitu ketika seorang Yahudi menagih hutang kepada Rasul dengan mengeluarkan perkataan yang tidak etis. Para sahabat yang menyaksikan sudah tersulut emosi, tetapi Rasul bersabda: "Biarkanlah ia bicara, karena ia berhak untuk itu" (Riwayat Bukhari-Muslim, Abu Daud dan alNasa'i). Peristiwa ini menunjukkan bahwa Rasulullah saw sebagai kepala negara Madinah memberikan persamaan hak kepada orang Yahudi yang notabenenya adalah warga negara. Dengan kata lain, setiap warga negara memiliki kewajiban-kewajiban dan hak-hak yang sama. Penyelenggara negara dilarang memperlakukan mereka dengan diskriminatif.

Ketiga, prinsip kebebasan (al-hurriyah). Prinsip ini sangat sentral di dalam ajaran Islam, sebab secara esensial, Islam mengandung arti liberalition (bebas), berarti bebas dari kenistaan, kejahatan, kezaliman, dan pemaksaan. Di masa Rasulullah saw. Kaum Yahudi dan Paganis diberi kebebasan untuk memeluk agama serta kepercayaannya masingmasing. Sejalan dengan pernyataan al-Qur'an:

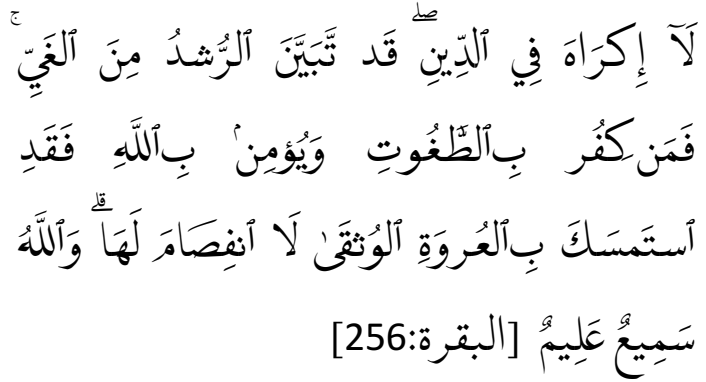

“Tidak ada paksaan dalam (menganut) agama (Islam), sesungguhnya telah jelas (perbedaan) antara jalan yang benar dengan jalan yang sesat. Barangsiapa yang ingkar kepada Tagut, dan beriman kepada Allah, maka sungguh dia telah berpegang (teguh) pada tali yang sangat kuat yang tidak akan putus. Allah Maha Mendengar, Maha Mengetahui" [QS alBaqarah/2:256].

Kebebasan memeluk agama, tertuang dalam rumusan Piagam Madinah: "Bagi orang Yahudi, agama mereka, dan bagi kaum Muslimin agama mereka pula" (Dokumen Piagam Madinah, n.d., Pasal 25). Dari sini terlihat jelas, bahwa Piagam Madinah telah memberikan landasan menjamin otonomi bagi kelompok yang beragama, yaitu kebebasan untuk memeluk serta melaksanakan suatu agama. Di samping itu, prinsip kebebasan ini juga menyangkut kebebasan berpendapat, yakni ketika mengajukan usul atau mengeluarkan argumentasi di kala musyawarah.

Substansi Piagam Madinah menegaskan cita-cita terciptanya tatanan masyarakat zaman Rasulullah saw yang Islami, dan sekaligus dapat menjadi tempat berlindung bagi umat lain dari berbagai suku dan agama. Piagam Madinah menjadi contoh suatu sistem dan konstitusi yang mewadahi masyarakat yang plural. Sangat beralasan jika Montgomery Watt dan Robert N. Bellah memandang Piagam Madinah yang disusun Rasulullah saw itu sebagai konstitusi termodern di zamannya.

Setidaknya ada dua nilai penting yang dapat diambil dari Piagam Madinah menyangkut prinsip demokrasi, dan masih relevan hingga saat ini. Pertama, peletakan 
prinsip integrasi sosial dan politik dalam sebuah negara Madinah. Ini merupakan nilai penting, mengingat masyarakat Madinah saat itu bersifat majemuk. Kedua, dasar penghormatan yang kukuh bagi sebuah kehidupan yang toleran dengan menjamin hak-hak warga negara non Muslim berupa perlindungan pada kehidupan dan harta benda mereka. Inilah sumbangan terbesar Piagam Madinah yang kemudian diadopsi oleh kehidupan modern dalam wujud "hak asasi manusia" (HAM).

Lahirnya Piagam Madinah bukanlah sebuah utopia yang artificial, atau latihan politisteoretis. Piagam Madinah telah memasuki sejarah tertulis sebagai sebuah dokumen hukum yang diterapkan secara sistematis dan konkret dari tahun 622 hingga $632 \mathrm{M}$. Berbeda dengan Amerika Serikat yang mengklaim sebagai kampium demokrasi, membutuhkan waktu sangat panjang untuk mewujudkan demokratisasi dalam kehidupan berbangsa dan bernegara.

Stobe Talbolt dalam bukunya "Democracy and the International Interest" mengatakan, sejak terbentuknya negara federasi pada tahun 1776, Amerika Serikat memerlukan waktu 11 tahun untuk menyusun konstitusi; 89 tahun untuk menghapus perbudakan, 144 tahun untuk memberi hak pilih pada kaum perempuan, dan 188 tahun untuk menyusun draf konstitusi yang melindungi seluruh warganya.

Namun demikian, Piagam Madinah tidak dapat dijadikan sebagai pembenar bagi pembentukan negara Islam, sebab Rasul sendiri dalam piagam itu tidak menyebut negara yang didirikannya sebagai negara Islam. Istilah "daulah Islamiyah" baru muncul saat Islam berhadapan dengan konsep Barat yang disebut nation state. Oleh karenanya, jika hendak dijadikan model, yang dapat diambil dari Piagam Madinah adalah nilai-nilai penting yang ada di dalamnya.

\section{Pembahasan}

Pada tahun 1949, UNESCO menyatakan, mungkin untuk kali pertama dalam sejarah, demokrasi disebut sebagai nama yang paling baik dan wajar untuk semua sistem organisasi politik dan sosial (Shoelhi, 2003:23). Ada beberapa catatan yang menjadi tantangan dan hambatan demokratisasi di dunia Islam ketika konsep demokrasi yang berasal dari Barat dikomparasikan secara doktrinal dengan Islam yang bersumber dari al-Qur'an dan Sunnah. Pertama, demokrasi adalah buatan akal manusia, bukan berasal dari wahyu. Karena itu, demokrasi tidak memiliki hubungan secara doktrinal dengan Islam.

Kedua, demokrasi berlandaskan dua ide, yaitu: kedaulatan di tangan rakyat dan rakyat sebagai sumber kekuasaan. Kedua ide tersebut dicetuskan oleh para filosuf dan pemikir di Eropa ketika mereka melawan para kaisar dan raja untuk menghapuskan ide hak ketuhanan atas rakyat. Dalam Islam, kedaulatan adalah pemilik syara', bukan milik rakyat. Ditegaskan QS al-Nisa'/4:59, perintah taat kepada Allah dan Rasulnya bersifat mutlak tanpa syarat, sedangkan taat kepada uli al-amri bersifat relatif. Dari segi bahasa, kata uli adalah bentuk jamak dari waliy yang berarti pemilik atau yang mengurus dan menguasai. Bentuk jamak dari kata tersebut menunjukkan bahwa mereka itu banyak, sedangkan kata al-amr adalah perintah atau urusan. Dengan demikian, uli al-amr ialah orang-orang yang berwenang mengurus urusan kaum Muslimin. Mereka adalah orang-orang yang diandalkan dalam menangani persoalanpersoalan kemasyarakatan. Ada yang berpendapat bahwa mereka adalah para penguasa/pemerintah. Ada juga yang mengatakan, mereka itu adalah ulama, dan pendapat lain menyatakan bahwa mereka adalah yang mewakili masyarakat dalam berbagai kelompok dan profesinya. Perlu dicatat, kata al-amr berbentuk ma'rifah atau definite. Ini menunjukkan banyak ulama membatasi wewenang pemilik kekuasaan itu hanya pada persoalan-persoalan kemasyarakatan, bukan menyangkut akidah atau keagamaan murni (Syihab, 2000:460461).

Ketiga, demokrasi adalah sistem pemerintahan mayoritas. Pemilihan penguasa dan anggota dewan perwakilan diselenggarakan berdasarkan suara mayoritas pemilih. Semua keputusan dalam lembagalembaga tersebut diambil atas dasar pendapat mayoritas. Di dalam Islam, suara mayoritas diambil untuk masalah-masalah yang belum dijelaskan dalam al-Qur'an dan menyangkut 
urusan yang memerlukan langkah segera. Misalnya Rasulullah saw bermusyawarah tentang strategi dalam menghadapi musuh pada perang Uhud. Penetapan kebijakannya atas dasar suara terbanyak (mayoritas). Karena itu, perkara yang sudah qath'i (pasti) seperti hukum halal dan haram tidak diperlukan lagi suara mayoritas.

Keempat, demokrasi menyatakan adanya empat macam kebebasan: 1) kebebasan beragama (freedom of religion); 2) kebebasan berpendapat (freedom of speech); 3) kebebasan kepemilikan (freedom of ownership); dan kebebasan bertingkah laku (personal freedom). Dalam Islam, kebebasankebebasan tersebut dapat diterima selagi tidak bertentangan dengan nilai-nilai etik yang termaktub dalam al-Qur'an dan Sunnah.

Dari keempat hal di atas, intinya bermuara pada kedaulatan rakyat. Lembaga legislatif dan eksekutif memiliki power, karena mempunyai legitimasi setelah menang dalam pemilu dan dipilih oleh rakyat. Petanyaannya, apa ada jaminan lembaga keterwakilan tersebut betulbetul menjadi lembaga perwakilan rakyat? Lalu, apakah rakyat yang disalahkan karena memilih orang-orang untuk duduk di lembaga legislatif dan eksekutif? Apabila ada adagium bahwa suara rakyat adalah suara Tuhan, apakah rakyat selalu benar? Benarkah suara terbanyak mencerminkan kebenaran? Bagaimana menentukan standar benar?

Inilah pangkal perdebatan Islam dan demokrasi. Politik dalam Islam dengan prinsip kedaulatan hanya pada Allah, sementara paham sekuler demokrasi bahwa kedaulatan absolut di tangan rakyat. Dalam demokrasi, produk hukum memerlukan konsultasi, sehingga produk hukum dan pengesahan kebijakan ditetapkan menurut kuorum dalam lembaga legislatif. Sementara dalam Islam, hanya Allah sebagai legislator dengan penerapan syariah. Maka produk hukum maupun kebijakan dalam Islam mengacu pada hukum Allah, sehingga siapa pun menjadi pemimpin sebuah negara memiliki panduan yang sejalan dengan al-Quran dan Sunnah. Apabila produk hukum melalui mekanisme lembaga legislatif hanya berdasarkan kesepakatan hasil suara terbanyak, tidak menjamin menghasilkan keputusan yang adil, karena rentan ditunggangi kepentingan politik kelompok tertentu.

Tentang hubungan Islam dan demokrasi telah menjadi perhatian luas pemikir muslim seperti al-Maududi, Muhammad Iqbal, Mahmud Thaha dan lain-lain. Pada prinsipnya tidak semua ajaran demokrasi relevan dengan ajaran Islam. Konsep theo-democracy, yaitu demokrasi yang religius menjadi salah satu alternatif dalam menjembatani pandangan di atas. Ketika demokrasi menjadi komitmen bagi negara untuk dipraktikkan, maka semua aspek kehidupan tidak lepas dari sentuhan demokrasi, termasuk agama. Agama yang bersifat dogmatis keyakinan absolut bagi pemeluknya harus masuk pada ruang perdebatan bagaimana agama bisa selaras, sejalan dan menemukan titik temu dengan demokrasi.

Di beberapa negara, praktik demokrasi agama tidak mengalami hambatan yang serius. Kesuksesan dalam memisahkan urusan agama dan politik (sekularisasi) merupakan pertimbangan dasar yang memperkuat asumsi tersebut. Di sisi lain, praktik agama yang banyak mengedepankan ajaran spiritual dan longgar dalam penerapan ritual termasuk salah satu pendorongnya. Di hampir semua negara di Eropa, Amerika Utara dan Australia di mana agama terpisah dari urusan politik sehingga menjadi urusan privat, demokrasi agama tidak mengalami hambatan.

Kondisi berbeda akan terlihat di negaranegara muslim terutama Asia dan Afrika Utara. Demokrasi agama tidak serta merta beriringan dengan praktik demokrasi politik. Bahkan pada banyak kasus, demokrasi politik masih dianggap tabu dan banyak pertentangan. Munculnya kelompok perlawanan seperti alQaeda, Boko Haram, al-Sabab, Jamaah Islamiyah bahkan Islamic State merupakan contoh bagaimana demokrasi masih mengalami perlawanan yang sangat keras. Apalagi ketika masuk pada demokrasi agama. Samuel P. Huntington mengatakan, kegagalan demokrasi di negara-negara Muslim antara lain disebabkan oleh watak budaya dan masyarakat Islam yang tidak ramah terhadap konsep-konsep liberalisme Barat (Huntington, 1997:112).

Pemerintahan Mursi di Mesir, yang didominasi kalangan Islamis tidak berhasil memenuhi ekspektasi rakyat, sehingga 
memunculkan gelombang demonstrasi besarbesaran untuk menuntutnya mundur. Hal ini memunculkan keraguan bahwa ideologi Islam tidak kondusif menjadi asas negara. Ikhwanisasi yang diluncurkan kelompok Islamis dan kegagalan meningkatkan ekonomi Mesir era pemerintahan Mursi, dijadikan alasan kuat oleh militer untuk menggulingkan penguasa. Sekarang 'politik zero-sum' dengan kembalinya militer ke politik, dan tidak ada harapan untuk penegakan demokrasi sejati. Padahal mulai akhir 2011/awal 2012 di Tunisia, Mesir, Yaman, Bahrain, dan Suriah, kaum Islamis memenangkan pemilihan: Partai Nahda di Tunisia, Partai Kebebasan dan Keadilan (sayap Ikhwan al-Muslimin), dan Partai al-Nour (Salafi) Partai-partai kaum Islamis tersebut memenangkan kursi terbanyak di Parlemen (Azra, 2020). Menurut Azra, fenomena yang terjadi di Mesir, yakni penggulingan Presiden Mesir oleh militer pada Kamis dini hari, 4 Juli 2013 meningkatkan ketidakpastian transisi demokrasi di Dunia Arab (Azra, 2016, p. 261).

Pasca perang dunia II, sebagian besar negara-negara Arab, kecuali Arab Saudi, mengadopsi 'ideologi sekuler' seperti Sosialisme, Komunisme, Baathisme, Nasseri; semuanya religius tidak ramah. Sebagian besar rezim adalah 'otoriterisme/kediktatoran militer'. Penentangan kuat dari kelompokkelompok Islam, terutama al-lkhwan alMuslimun dan berbagai kelompok spinter (semua sekarang disebut 'Islamis'), sangat dipengaruhi oleh kesukuan dan sektarianisme. Dinamika dalam dua dasawarsa milenium baru (2000 dan seterusnya) tidak membuat dunia Muslim berubah. Ini adalah salah satu periode paling gelap dalam sejarah sebagian besar dunia Muslim (Asia Selatan, Arab, dan Afrika), karena tidak ada tanda-tanda baik bahwa krisis dapat diselesaikan segera, seperti: kekerasan dan terorisme yang merajalela di negara-negara mayoritas Muslim (Arab, Asia Selatan, dan Afrika) yang dilakukan ISIS, al-Qaidah, Taliban, Boko Haram, al-Shabab. Konflik yang terusmenerus akibat perang saudara di Yaman, Libya, Irak, Suriah, dan Afghanistan, menyebabkan migrasi massal dari Dunia Arab dan Asia Selatan ke Eropa, Asia Tenggara, Amerika Utara, dan Australia, sehingga menciptakan kesengsaraan manusia (Azra, 2020).

Sektarianisme dan kesukuan agama yang kuat serta tidak ada jalan tengah dan kekuatan penyeimbang Islam wasathiyyah melahirkan konflik dan kekerasan di Afghanistan, Pakistan, Bangladesh, Sudan, Negeria, dan Somalia. Muslim di belahan Barat semakin menghadapi kesulitan karena munculnya Islamo-fobia yang berasal dari penurunan ekonomi di beberapa negara Eropa, kekerasan dan terorisme yang dilakukan oleh umat Islam, ekspresi agamabudaya yang tidak sensitif dari beberapa Muslimah seperti mengenakan jilbab penuh (burqa dan/atau niqab). Konsekuensinya, gangguan (tekanan) terhadap Muslim di Barat meningkat. Demikian pula kekerasan dan terorisme yang dilakukan oleh umat Islam di negara-negara Eropa, Amerika Utara, Asia Tenggara, Asia Tengah, mempercepat sentimen anti-Islam dan anti-Muslim (Azra, 2020).

Gambaran di atas menunjukkan, bahwa mayoritas model dan sistem negara-negara Islam di dunia saat ini bukan demokrasi. Berdasarkan rating indeks negara demokratis yang dibuat Freedom House di Amerika Serikat untuk tahun 1997/1998, ternyata dari 48 negara-negara Islam, hanya 8,7 persen yang digolongkan sebagai negara demokratis, 30 persen semi demokratis, dan sebagian besarnya $(60,9$ persen) digolongkan sebagai negara otoriter. Sedangkan negara-negara non Muslim, 23,3 persen otoriter, 30,1 persen semi demokratis, dan 46,6 persen demokratis (Shoelhi, 2003:26). Sejak tahun 1999, Indonesia menjadi negara demokrasi terbesar ketiga setelah India dan Amerika Serikat, juga sebagai negara berpenduduk Muslim terbesar di dunia.

Muslim Indonesia menerima demokrasi sejak masa kemerdekaan. Pada umumnya mereka memandang bahwa Islam sesuai dengan demokrasi. Muslim Indonesia berpartisipasi dalam semua tahapan demokrasi Indonesia. Wanita Muslim semakin diberi kesempatan menduduki lembaga legislatif dan eksekutif, mulai dari Presiden (Megawati Soekarnoputri 2001-2004), gubernur, walikota, atau kepala kecamatan. Transisi Indonesia ke demokrasi relatif 'lancar' karena masyarakat sipil yang kuat berbasis Islam seperti NU, Muhammadiyah 
dan lain-lain. Tidak ada civil society yang sebanding di negara-negara Arab, yang dihancurkan oleh kediktatoran militer. Masyarakat sipil berbasis Islam ini memainkan peran yang sangat penting dalam membangun budaya kewarganegaraan. Dengan civil society yang kuat, kebebasan pers, dan jejaring sosial yang dinamis, sangat tidak mungkin militer Indonesia akan kembali mendominasi politik. Karena itu, Islam dan Muslim adalah faktor penting dalam politik Indonesia (Azra, 2020).

Di negara-negara ASEAN, terutama Indonesia, demokrasi agama juga mengalami tantangan dan hambatan. Kasus Ahmadiyah, Syiah, Majlis Tafsir al-Qur'an (MTA), dan Front Pembela Islam (FPI) yang belakangan banyak memperoleh sorotan merupakan contoh nyata bahwa demokrasi agama mengalami tantangan yang serius. Pertentangan yang berakhir kekerasan atas nama agama terus menggelinding dan seolah tidak pernah berakhir. Munculnya ragam aliran dalam ormas berdampak pada dinamika internal yang 'tak berujung' dalam menyikapi persoalan demokrasi agama. Keharmonisan pandangan demokrasi agama hanya pada tataran elite, yang berlatar pendidikan lebih baik dengan didukung oleh pengalaman yang luas, sementara organ di bawahnya tidaklah demikian. Ada perbedaan yang mencolok antara elite yang berada pada level tertinggi dengan elite yang berada pada level basis.

Pengalaman sejarah, beberapa kelompok sempalan tidak menerima Pancasila dan berusaha membentuk Negara Islam (DI /TII, NII) pada akhir 1950-an. Mereka gagal karena tidak ada dukungan dari Muslim arus utama. Saat ini ada kelompok berorientasi transnasional seperti HTI yang ingin membentuk kekhalifahan, dan kelompok Salafi transnasional yang berusaha memurnikan pemahaman dan praktik Islam Indonesia. Ada kesalahpahaman dan miskonsepsi tentang daulah Islamiyah dan khilafah, juga tentang Islam idealistik Salafi. Azyumardi Azra menyatakan, tidak ada satu pun model negara Islam di dunia ini yang benarbenar dapat dijadikan prototipe negara Islam, sekalipun Arab Saudi, Pakistan, atau Iran. Klaim negara-negara ini sebagai negara Islam, realitasnya belum memenuhi kriteria negara Islam yang ideal. Arab Saudi yang seringkali mengklaim diri sebagai negara Islam, menerapkan sistem pemerintahan berdasarkan kerajaan, padahal dalam Islam tidak ada konsep kerajaan (Azra, 2000:195).

\section{PENUTUP}

\section{Simpulan}

Islam sangat menjunjung esensi demokrasi, seperti penghargaan terhadap kesederajatan manusia, kebebasan berpikir, dan kemerdekaan individu. Secara doktrinal, Islam dan demokrasi adalah dua hal yang berbeda, namun secara substantif ada prinsip-prinsip demokrasi yang sesuai dengan ajaran Islam. Prinsip keadilan dalam penegakan hukum, persamaan dalam kehidupan bermasyarakat, berbangsa dan bernegara, serta kebebasan berpendapat, beragama dan berkeyakinan. Prinsip-prinsip ini secara ideal tertuang dalam dokumen tertulis, yaitu Piagam Madinah.

Piagam Madinah merupakan sebuah konsensus antara berbagai golongan, baik ras, suku, maupun agama yang paling demokratis sepanjang sejarah. Piagam Madinah telah mewariskan prinsip-prinsip yang kukuh dalam membangun masyarakat pluralistik yang harmonis. Fakta sejarah menunjukkan, negara Madinah menjadi contoh konkret keserasian hidup bernegara. Sebelum negara demokrasi menemukan bentuknya di Barat, Rasulullah saw telah meletakkan dasar-dasar demokrasi yang sanggup menjawab kebutuhan bermasyarakat dan bernegara.

Sebagai produk peradaban, Piagam Madinah banyak memberi pelajaran penting bagaimana umat beragama membangun tatanan masyarakat yang adil dan manusiawi, serta bagaimana umat manusia membangun system peradaban yang tercerahkan dan memberi manfaat untuk umat manusia.

Realitas negara-negara Islam di Timur Tengah, Asia Selatan, dan Afrika yang dilanda konflik perang saudara, aksi-aksi kekerasan, serta terorisme, dengan sistem pemerintahan yang otoriter-diktator tidak mewakili sebagai "negara Islam" yang ideal. Format negara Islam yang diklaim oleh mereka tidak dapat membuktikan secara riil model negara Islam yang dicontohkan oleh Rasulullah saw yang mengedepankan substansi, bukan formalistik. Gagalnya demokratisasi di kebanyakan negara 
Islam, karena pandangan yang legalistik dan formalistik dalam melihat relasi antara Islam dan demokrasi. Karena itu, perlu pendekatan substantivistik terhadap ajaran Islam untuk memahami "makna demokrasi."

Indonesia bukan negara Islam, namun Indonesia adalah negara berpenduduk Muslim terbesar di dunia. Indonesia juga merupakan negara demokrasi terbesar ketiga setelah India dan Amerika Serikat. Islam Indonesia adalah 'Islam wasathiyyah', yaitu Islam moderat dengan tradisi inklusif, toleransi, dan koeksistensi damai dengan penganut agama lain. Islam Indonesia adalah yang paling tidak diArab-kan, tetapi tetap Islami. Mayoritas Muslim Indonesia menganggap Islam dan demokrasi itu kompatibel, sehingga tidak mempersoalkan Pancasila sebagai dasar negara. Paradigma ini dapat dikategorikan pada pemahaman "Islam substantif." Aksi-aksi kekerasan dan intoleransi yang mengatasnamakan "jihad" adalah bagian kecil yang bersifat kasuistik, dan tidak dapat dikategorikan sebagai kegagalan demokrasi di Indonesia yang mayoritas penduduknya Muslim.

\section{Rekomendasi}

Peningkatan kualitas kehidupan umat beragama, harmoni sosial dan kerukunan umat beragama merupakan salah satu sasaran strategis program Kementerian Agama. Sebagai institusi yang mewadahi pelatihan di bidang Pendidikan dan keagaman, Pusdiklat hendaknya memfasilitasi secara intens diskusidiskusi, seminar, bedah buku, dan kegiatankegiatan keilmuan yang membahas tentang wawasan kebangsaan, moderasi beragama, dan demokrasi.

Materi "Islam dan Demokrasi" seharusnya dijadikan salah satu Mata Diklat dalam Pelatihan Moderasi Beragama, sehingga ada keseimbangan dalam memahami radikalisme, ekstremisme, terorisme, intoleransi, yang lebih tendensius pada Islam. Pengenalan Islam yang rahmatan lil 'alamin melalui nilai-nilai demokrasi dalam Islam harus dikenalkan kepada peserta pelatihan. 


\section{DAFTAR PUSTAKA}

'Ulyan, Rusydi Muhammad, D., \& Al-Ruriy, Fithan 'Abd al-Rahman, D. (1986). Ushul al-Din al-Islamiy (Cet. ke-2). Baghdad: Mathba'ah al-Irsyad.

Abdillah, M. (2001). "Syura dan Demokrasi" dalam Artani Hasbi, Musyawarah dan Demokrasi (1st ed.). Jakarta: Gaya Media Pratama.

Ahmad, B. (1979). Muhammad and The Jews, A Re-Examination. New Delhi: Vikas Publishing House.

Ali, M. D. (1990). Asas-Asas Hukum Islam (Hukum Islam I): Pengantar IImu Hukum dan Tata Hukum Islam di Indonesia. Jakarta: Rajawali Press.

Azhary, M. T. (1992). Negara Hukum : Suatu Studi Tentang Prinsip-Prinsipnya Dilihat Dari Segi Hukum Islam, Implementasinya pada Periode Negara Madinah dan Masa Kini. Jakarta: Bulan Bintang.

Azra, A. (2000). Islam Substantif (1st ed.). Bandung: Mizan.

Azra, A. (2016). Transformasi Politik Islam; Radikalisme, Khilafatismedan Demokras. Jakarta: Prenadamedia Group.

Azra, A. (2020). "Perkembangan Demokratisasi di Indonesia dan Dunia Muslim Kontemporer," disampaikan dalam perkuliahan Doktor Pengkajian Islam, Contemporary Islamic World.

Boisard, M. A. (1980). Humanisme dalam, Terjemanahan. Jakarta: Bulan Bintang.

Budiardjo, M. (2004). Dasar-Dasar Ilmu Politik. Jakarta: Gramedia.

Depdikbud. (1999). Kamus Besar Bahasa Indonesia (10th ed.). Jakarta: Balai Pustaka.

Dokumen Piagam Madinah. (n.d.).

Esposito, J. L., \& Picatori, J. P. (1991). Islam and Democraty. Middle East Journal, 4(3).

Hadimulyo. (1993). Fundamentalisme Islam: Istilah yang dapat menyesatkan. Ulumul Qur 'an, 4(3).

Haikal, M. H. (1982). Sejarah Hidup Muhammad, terjemahan Ali Audah. Jakarta: Pustaka Jaya dan Tintamas.

Hasbi, A. (2001). Musyawarah dan Demokrasi (1st ed.). Jakarta: Gaya Media Pratama.

Huntington, S. P. (1997). The Clash of Civilizations: Remaking of The World Order. New York: Simon and Schuster.

Huwaydi, F. (1993). Al-Islam wa al-Dimuqrathiyyah. Kairo: Markaz Al-Ahram.

Islam, D. J. B. M., Islam, D. U. A., \& RI, P. S. K. A. (2010). Al-Qur'an dan Terjemahnya. Jakarta: PT. TEHAZED.

Kerr, M. H. (1966). Islamic Reform: The Political and Legal Theoris of Muhammad Abdul and Rashid Rida. Berkeley and Los Angeles: University of California Press.

Lewis, B. (1983). Kebangkitan Islam Di Mata Seorang Sarjana Barat (Terjemahan; H. Bagir, Ed.). Bandung: Mizan.

Ma'luf, L. (2003). Al-Munjid fi al-Lughah wa al-A'lam (Cet. ke-40). Beirut: Dar al-Masyriq.

Madjid, N. (1994). "Agama dan Negara dalam Islam Telaah atas Fiqh Siyasy Sunni” dalam Budhy MunawarRahman (ed.), Kontekstualisasi Doktrin Islam Dalam Sejarah (Cet. ke-1). Jakarta: Paramadina.

Maududi, A. al-A. al. (1960). Islamic Law and Constitution. Lahore: Islamic Publication Ltd.

Maududi, A. al-A. al. (1984). Khilafah dan Kerajaan, terjemahan Muhammad al-Baqir. Bandung: Mizan.

Merriam-Webster, A. (1984). Webster's Ninth Collegiate Dictionary. Springfield Massachusetts: Merriam-Webster Inc.

Moleong, L. (1991). Metodologi Penelitian Kualitatif (Cet. ke-3). Bandung: PT Remaja Rosdakarya.

Nasr, S. H. (1983). Islam dalam Cita dan Fakta (Terjemahan; A. Wahid \& H. Wahid, Eds.). Jakarta: Leppenas.

Prasetyo, H. (1994). Pancasila as an Islamic Ideology For Indonesian Muslim. Studia Islamika, 1(1). 
Qardhawy, Y. (1997). Min Figh al-Daulah fi al-Islam (erjemahan). Jakarta: Robbani Press.

Rais, M. D. (2001). Al-Nazhariyyat al-Siyasiyyah al-Islamiyyah (Terjemahan). Jakarta: Gema Insani Press.

Rasjidi, H. M., P. D. (1989). Koreksi Terhadap Dr. Harun Nasution Tentang "Islam Ditinjau Dari Berbagai Aspeknya" (Cet. ke-3). Jakarta: Bulan Bintang.

Salamadian. (2018). Pengertian Demokrasi: Prinsip, Sejarah, Ciri Ciri dan Macam Macam Demokrasi. Retrieved June 30, 2020, from https://salamadian.com/ website: https://salamadian.com/pengertian-demokrasi/

Shoelhi, M. (2003). Demokrasi Madinah: Model Demokrasi Cara Rasulullah (Cet. ke-1). Jakarta: Republikas.

Sjadzali, M. (1990). Islam dan Tata Negara: Ajaran, Sejarah, dan Pemikiran (Cet. ke-2). Jakarta: UI Press.

Sudjana, E. (1998). Ham, Demokrasi, dan Lingkungan Hidup Perspektif Islam (Cet. ke-1). Bogor: As-Syahidah.

Syihab, M. Q. (2000). Tafsir Al-Mishbah (Cet. ke-1). Jakarta: Lentera Hati.

Syihab, M. Q. (2018). Islam yang Saya Anut: Dasar-Dasar Ajaran Islam (Cet. ke-3). Jakarta: Lentera Hati.

Thawil, R. al. (1984). Al-Da'wah fi al-Islam Aqidah wa Manhaj. Mekkah al-Mukarramah: Rabithah 'Alam alIslamiy.

Watt, W. M. (1987). Pergolakan Pemikkiran Politik Islam (Terjemahan; H. F. Zarkasyi, Ed.). Jakarta: Bina Cipta. 